\title{
MENUMBUHKAN BUDAYA MEMBACA ANAK-ANAK PEDESAAN MELALUI PENGAKTIFAN KEMBALI PERPUSTAKAAN KOMUNITAS DI SRIKATON PONDOK KELAPA BENGKULU TENGAH
}

\section{INCREASING READING ENTHUSIASM AMONG SCHOOL-AGE CHILDREN BY REACTIVATING THE COMMUNITY LIBRARY IN RURAL DISTRICT OF SRIKATON CENTRAL BENGKULU}

\author{
Oleh: \\ Sri Handayani Hanum, Purwaka, Purwadi Eka Tjahjono, dan Heni Nopianti \\ Jurusan Sosiologi, Fakultas Ilmu Sosial dan Politik, Universitas Bengkulu. \\ hanum_bkl@yahoo.com
}

\begin{abstract}
This community service activity was conducted in the Village of Srikaton, Sub-District of Pondok Kelapa, Central Bengkulu District. The aim is to increase reading enthusiasm among school-age children. Therefore, the target of this activity is the children of local villages and surrounding areas that are still studying in primary and secondary education levels. This activity focused on increasing children's interest in the use of village library that had been passive, so that the library is active again. This service activity was carried out in the form of a drawing competition/coloring pictures, writing stories, and story telling. In realizing the goal of this community service activity, steps that have been made are: (a) a dialogue between the team of this community service with some village officers and community leaders to discuss the reactivation of the village library of Srikaton; $(b)$ the placement of a volunteer who is competent in managing the village library; $(c)$ the dissemination of library services, (d) the donation of recent books to the local village library and the library of SD Negeri 7 Srikaton (State Primary School 7 Srikaton); (e) conducting an educational event in the village library, $(f)$ monitoring and advising on the management and library services to the village library of Srikaton and the school library of SD Negeri 7 Srikaton. The results of this community service activity are as follows: the village library, which previously was passive, has been active again since 17August, 2014. The activation was done by the placement of a voluntary librarian in this library. Library is open two days a week, which is Saturday from 16:00 to 18:00 and Sundays from 10:00 to 13:30. The socialization of the village library services was conducted by the team through a local person, who is the village library volunteer, and the teachers of SD Negeri 7 Srikaton. The team also donated 86 titles of books (143copies) worth Rp5.029.800,-. Several educative competition activities based on library collections were done by holding a drawing/coloring contest, summarize the story books, and story-telling. Monitoring and providing consultation on library management conducted by the team once a month periodically from May 2014 until April 2015.
\end{abstract}

Keywords: Community Library Reactivation, School Age Children, Reading Enthusiasm 


\section{PENDAHULUAN}

Perpustakaan Komunitas Desa (perpusdes) Srikaton pernah mencapai puncak kesuksesan pengelolaan dalam ajang lomba perpustakaan tingkat nasional pada November 2012. Perpustakaan ini berhasil mewakili Provinsi Bengkulu dan mampu menempati peringkat II sebagai pemenang nasional dalam kategori Taman Bacaan Masyarakat (TBM). Dukungan Pemerintah Kabupaten Bengkulu Tengah beserta kerjasama pembinaan dan pendampingan oleh Tim dari Perpustakaan Wilayah Provinsi Bengkulu dengan Tim Pengabdian pada Masyarakat dari Universitas Bengkulu (Tim PPM UNIB) berhasil mengantarkan Perpustakaan Komunitas Desa Srikaton menempati posisi terhormat di tingkat nasional.

Sayang sekali setelah keberhasilannya itu, sejak Maret 2013 operasional layanan sirkulasi buku perpustakaan mengalami kemacetan. Ketiadaan relawan mahasiswa yang membantu mengelola perpustakaan komunitas sebagai akibat dari ketiadaan program pengabdian lanjutan menjadi faktor penyebabnya. Petugas perpustakaan yang ada yang ditugaskan oleh pemerintah desa tidak mampu menjalankan fungsi pengelolaan dan pelayanannya. Pengelolaan perpustakaan tidak intensif ditangani, serta keberadaan perpustakaan tidak lagi dimanfaatkan, dan koleksinya pun kurang berkembang. Bahkan disayangkan bahwa bantuan/hibah koleksi pustaka dari Bank Indonesia masih banyak yang belum diolah dan hanya tersimpan di dalam kardus serta tidak bisa dimanfaatkan masyarakat.

Kegiatan ini dirancang dengan menempatkan seorang pengelola perpustakaan yang memiliki basis ilmu perpustakaan yang nantinya bekerja bersama-sama dengan relawan setempat yang ditunjuk oleh pemerintahan desa untuk mengelola perpustakaan dimaksud. Dampak kegiatan antara lain akan memberi akses bacaan edukatif dan menghibur bagi anak-anak pedesaan yang cukup bermanfaat dalam rangka pencerdasan mereka.

Ada beberapa alasan penting dilakukannya program penumbuh-kembangan budaya membaca pada anak-anak dan pendampingan pengelolaan perpustakaan tersebut. Pertama, program ini diharapkan mampu meningkatkan pengetahuan dan semangat belajar masyarakat yang berarti mendukung upaya pemerintah dalam mencerdaskan bangsa. Kedua, melalui perpustakaan komunitas dapat melengkapi kekurangan penyelenggaraan perpustakaan sekolah SD Negeri 7 Pondok Kelapa yang berlokasi di desa setempat (Hanum, 2013). Ketiga, keberadaan perpustakaan keliling dan perpustakaan masjid setempat yang diharapkan selama ini dapat menumbuhkan dan meningkatkan minat baca belum nampak jelas dampak riilnya. Perpustakaan keliling sangat terbatas jangkauan dan intensitas pelayanannya. Sedang perpustakaan masjid mengalami kendala dalam hal pengelolaan dan dukungan finansialnya. Keempat, perpustakaan komunitas memberi harapan pada kelompok masyarakat marjinal, terutama para pelajarnya, untuk memiliki akses terhadap bahan bacaan yang mutakhir, variatif, dan berkualitas. Oleh karena itu, perpustakaan komunitas akan dapat menjadi media untuk pengayaan ilmu pengetahuan dan peningkatan prestasi belajar siswa di lingkungan perpustakaan tersebut. Kelima, 
perpustakaan komunitas dapat dijadikan tempat rekreasi alternatif yang edukatif dan mencerahkan bagi masyarakat tanpa harus mengeluarkan biaya karena layanannya dirancang gratis. Keenam, membentuk citra positif UNIB sekaligus sebagai bentuk tanggungjawab sosial perguruan tinggi dalam pembangunan masyarakat.

Sebagian besar masyarakat Indonesia, terutama pelajar ditengarai belum menjadikan kegiatan membaca sebagai kebutuhan yang mendasar, padahal sebenarnya aktifitas membaca merupakan salah satu gerbang untuk mendapatkan informasi dan wawasan, menguasai pengetahuan, dan mewarnai sikap hidup. Bertambahnya ilmu bagi seseorang didapat dari membaca, bahkan dengan membaca pula kemampuan berbahasa seseorang dapat terus ditumbuhkan. Masyarakat di negara maju ditengarai oleh kebiasaan membaca yang cukup tinggi, yaitu bahwa aktifitas membaca sudah menjadi suatu kebutuhan dan budaya masyarakatnya. Lazim ditemukan dalam tranportasi publik bila para penumpangnya saling berdiam diri karena masing-masing tengah asyik membaca buku selama dalam perjalanan. Sementara itu di Indonesia kondisi tingkat membaca masyarakat masih rendah, budaya mendengar justru yang cenderung menjadi kebiasaanmembaca sangat diperlukan. Dengan membaca para pelajar dapat memperluas wawasan dan pandangannya, dapat menambah dan membentuk sikap hidup yang baik, menjadi hiburan serta menambah ilmu pengetahuan. Ibarat pepatah "membaca membuka cakrawala dunia", maka "perpustakaan adalah kuncinya". Artinya dengan membaca segala pengetahuan akan diketahui dan melalui perpustakaanlah pengetahuan itu akan selalu dapat diperoleh sepanjang masa karena di sanalah tempat sumber ilmu itu (yang berupa buku baik cetak maupun digital) berada. Dalam pengertian mutakhir perpustakaan diterjemahkan sebagai salah satu sarana pelestari bahan pustaka sebagai hasil budaya dan mempunyai fungsi sebagai sumber kehidupan, teknologi, dan kebudayaan dalam rangka mencerdaskan kehidupan bangsa dan menunjang pelaksanaan pembangunan nasional (Mudjito, 2001).

Bagi setiap lembaga pendidikan dan ilmu pengetahuan perpustakaan merupakan salah satu media yang sangat vital dalam setiap kegiatan pendidikan, pengajaran, dan penelitian (research). Perpustakaan bahkan merupakan inti dari setiap penyelenggaraan program pendidikan dan pengajarannya itu, ia menjadi the heart of the educational programs (Nurhayati, 1987:1). Hal itu dapat dipahami, karena fungsi universal dari setiap pendidikan adalah bahwa ia harus mampu selalu berdiri di garis depan dari perubahanperubahan yang terjadi di masyarakat, mengingat pendidikan dan anak didik selalu involved (saling bertautan) dengan hal-hal yang terjadi di dalam masyarakat di luar bidang sekolahnya. Maka dari itu terkandung arti bahwa pada dasarnya tanggungjawab pendidikan sebenarnya tak hanya diselenggarakan oleh jalur formal melalui sekolah saja, akan tetapi juga melalui jalur nonformal yang dipikul oleh komunitas masyarakat. Oleh karena itu, diperlukan adanya sarana komunikasi informasi ilmu pengetahuan untuk disampaikan kepada masyarakat yang berupa perpustakaan. Tidak mustahil bahwa adanya perpustakaan yang dikelola oleh komunitas dapat menjadi unsur yang mendukung penyelenggaraan pendidikan luar sekolah. 
Dalam hal penyelenggaraan perpustakaan di tingkat masyarakat, pemerintah Indonesia telah memvasilitasi dengan perangkat perundangannya yaitu Undang-Undang Nomor 43 Tahun 2007 tentang Perpustakaan dimana disebutkan bahwa Perpustakaan Desa merupakan salah satu jenis perpustakaan umum yang menjadi kewajiban pemerintah desa. Di era sebelumnya ketentuan tentang perpustakaan desa diatur dalam Instruksi Menteri Dalam Negeri Nomor 28 Tahun 1984, kemudian diperbarui dengan Keputusan Menteri Dalam Negeri Nomor 09 tahun 1988 dan Instruksi Menteri Dalam Negeri Nomor 21 tahun 1988 serta diperbarui lagi dengan Keputusan Menteri Dalam Negeri dan Otonomi Daerah Nomor 3 Tahun 2001. Di dalam Kepmen maupun instruksi Mendagri tersebut disebutkan bahwa perpustakaan umum yang berada di Desa mempunyai fungsi : (a) menghimpun dan mengelola bahan pustaka dan informasi; (b) memelihara dan melestarikan bahan pustaka dan informasi (c) mengatur dan mendayagunakan bahan pustaka dan informasi, sebagai pusat kegiatan belajar, pelayanan informasi, penelitian dan menumbuhkan minat dan kebiasaan membaca bagi seluruh lapisan masyarakat (Sutarno, 2008).

Fungsi dan peranan perpustakaan adalah: (a) menyediakan buku-buku, majalah dan bahan-bahan lain yang diperlukan pembaca; (b) menyediakan bahan penunjang dan penelitian; (c) menyediakan bahan bacaan lain seperti koran, novel, dan sebagainya sehingga mempunyai fungsi rekreatif dan pengembangan hobi; (d) memenuhi kebutuhan khusus yang berhubungan dengan subjek sasaran penunjang; (e) membantu para siswa untuk keperluan sehari-hari akan informasi tentang daerah, statistik, dan kesusastraan.

\section{METODE PENGABDIAN}

Langkah-langkahuntuk merealisasi tujuan PPM ini meliputi(a) dialog antara Tim Pengabdian Dosen dengan perangkat desa untuk membicarakan pengaktifan kembali layanan perpustakaan desa, (b) penempatan tenaga sukarelawan pengelola perpustakaan yang kompeten, (c) sosialisasi layanan Pusdes, (d) pemberian hibah buku bacaan pada Pusdes Srikaton dan pada Perpustakaan SDN 7 Srikaton, (e) perlombaan edukatif yang diselenggarakan di perpustakaan desa, (f) monitoring dan konsultasi pengelolaan dan layanan Pusdes Srikaton dan Perpustakaan SDNegeri 7 Pondok Kelapa (Srikaton).

Keterkaitan kegiatan pengabdian pada masyarakat ini adalah terjalinnya kemitraan dalam upaya pencerdasan bangsa/pendidikan masyarakat antara Universitas Bengkulu khususnya Tim Jurusan Sosiologi dengan perangkat pemerintahan Desa Srikaton dan Pamong Didik Sekolah Dasar Negeri 7 Srikaton, Pondok Kelapa. Sasaran programnya adalah untuk memberikan sarana rekreasi alternatif yang bersifat edukatif serta mempermudah akses komunitas masyarakat marjinal pedesaan terutama anak-anak usia sekolah terhadap bahan-bahan bacaan yang bisa mendukung peningkatan pengetahuan dan prestasi belajar mereka. Reaktifasi perpustakaan desa dengan demikian juga dapat menjadi mitra Sekolah Dasar Negeri 7 Pondok Kelapa yang lokasinya ada di desa setempat dalam menyediakan sumber-sumber pustaka pendukung pembelajaran. Kemitraan ini akan 
membawa citra positif bagi UNIB sebagai lembaga yang peduli pada pengembangan kualitas pendidikan di masyarakat.

\section{HASIL DAN PEMBAHASAN}

Launching terhadap dibukanya kembali aktifitas pelayanan Perpustakaan Desa Srikaton dilakukan pada saat Upacara Peringatan Hari Ulang Tahun Proklamasi Kemerdekaan Republik Indonesia ke-69 yang dilaksanakan pada Minggu pagi tanggal 17 Agustus 2014 mulai jam 07.00 bertempat di Lapangan Desa Srikaton. Pada kesempatan ini Kepala Desa bertindak sebagai Inspektur Upacara dan dihadiri siswa-siswi sekolah dari seluruh lembaga pendidikan formal yang berada di wilayah Desa Srikaton yaitu SDN 7, SMPN, dan SMKN beserta Pamong Didik dan Kepala Sekolah; Para Perangkat Desa; Wakil Remaja Desa; Kelompok Koperasi; Wakil PKK; Kelompok Lansia; Perwakilan Mahasiswa Universitas Muhammadiyah Bengkulu dan Sekolah Tinggi Agama Islam Negeri Bengkulu yang tengah mengikuti program Kuliah Kerja Nyata di Desa Srikaton selama 1 Juli hingga 31 Agustus 2014. Dengan demikian hal ini sekaligus merupakan bentuk sosialisasi akan adanya kegiatan perpustakaan kembali.

Untuk menjamin efektifitas keterlaksanaan dan ketercapaian tujuan program PPM maka seorang warga Desa Srikaton alumnus Program Studi D3 Perpustakaan UNIB oleh Tim PPM ditempatkan sebagai tenaga sukarela pengelola perpustakaan desa setelah mendapatkan ijin dari Kepala Desa dan Sekretaris Desa. Oleh Kepala Desa, relawan ini diberi kewenangan memegang kunci pintu Balai Desa dan kunci pintu ruang perpustakaan. Hal ini dimaksudkan agar relawan lebih mandiri dan tidak mengalami kendala ketika harus keluar masuk gedung saat harus menjalankan misi layanan Pusdes kepada pengguna. Sebagai insentif Relawan maka Tim PPM memberikan biaya pengganti kebutuhan transportasi.

Langkah awal yang dilakukan relawan untuk mereaktivasi Pusdes adalah memeriksa kembali penataan ruangan dengan cara membersihkan ruangan, sedikit mengatur kembali tata letak perabotan dan bahan pustaka, mengatur ventilasi, dan mengatur pencahayaan sesuai dengan standar minimal penyelenggaraan perpustakaan. Ruangan diatur sedemikian rupa agar baik petugas maupun pengunjung merasa nyaman berada di perpustakaan. Penataan ruangan juga ditujukan agar pencahayaan ruangan sesuai dengan kebutuhan pelestarian bahan pustaka dan kebutuhan terangnya ruangan bagi para pengunjung yang membaca di ruangan perpustakaan. Ruangan diusahakan bercahaya cukup tetapi tidak berlebihan. Pencahayaan yang kurang akan mengakibatkan ruangan lembab dan merangsang timbulnya jamur yang merusak bahan pustaka. Sebaliknya pencahayaan yang berlebihan akan menyebabkan kondisi fisik bahan pustaka akan cepat usang.

Setelah ruangan selesai ditata kembali selanjutnya dilakukan pensortiran dan penataan kembali koleksi buku yang ada dalam rak buku sesuai dengan blok-blok klasifikasinya; juga pengolahan buku (katalogisasi) yang belum terklasifikasi; dan 
menyiapkan kebutuhan layanan sirkulasi. Proses pengolahan bahan pustaka yang belum dikatalogisasi relatif membutuhkan waktu yang tidak sedikit karena terdiri dari beberapa tahapan. Jumlah buku yang masih harus diolah dan diberi perlengkapan jumlahnya mencapai hampir sekitar 400 eksemplar sedangkan petugas (relawan pengelola) yang ada hanya 1 orang. Pengolahan buku sebanyak itu oleh satu orang petugas dengan jam kerja 2 jam per hari 2 kali per minggu membutuhkan waktu kira-kira hingga 4 bulan. Setiap bahan pustaka (buku, dll) sebelum siap dilayankan (dijajarkan di rak dan dipinjamkan) kepada pengguna perlu diinventarisasi, diklasifikasi, dikatalogisasi, dan diberi perlengkapan buku. Tahapan-tahapan ini merupakan prosedur standar dalam pengolahan bahan pustaka.

Setelah dipandang siap layan maka secara resmi aktivitas pelayanan sirkulasi Pusdes Srikaton dibuka kembali mulai 6 September 2014. Jam buka peminjaman buku keluar dilayani setiap hari Sabtu jam 16.00-18.00 dan Minggu jam 10.00-13.30. Untuk peminjaman "baca di tempat" dilayani setiap hari kerja Kantor Desa di bawah pemantauan Sekretaris Desa. Selama kurun September-Nopember 2014 pengunjung yang hadir di Pusdes $80 \%$ adalah anak-anak siswa SD dan sedikit siswa SMP. Di Hari Minggu rata-rata jumlah pengunjung mencapai 14 orang dan di hari Sabtu rata-rata 7 orang, sementara di hari lain pada jam Kantor Desa rata-rata hampir tidak ada, kalaupun ada hanya 1 atau 2 orang. Dalam beberapa kali keadaan khusus Relawan perpustakaan mengatakan sesekali membuka Pusdes di luar hari layanan karena ada anak-anak (baik SD maupun SMP) yang membutuhkan buku-buku bacaan untuk menyelesaikan tugas sekolah.

Jumlah buku yang tersedia di Pusdes sekitar 1.000 eksemplar terdiri dari beberapa buku pelajaran tingkat Sekolah Dasar, fiksi, ide ketrampilan kreatif, pengetahuan umum, kesehatan, psikologi, ekonomi produktif, keagamaan, dll. Koleksi yang ada diperoleh dari sumbangan/hibah yang berasal dari Perpustakaan Daerah Propinsi Bengkulu, Bank Indonesia, Tim PPM UNIB tahun 2011 dan 2012, dan masyarakat umum. Sayang sekali, dari pantauan kartu buku, diketahui bahwa koleksi hibah buku sebenarnya banyak yang tidak termanfaatkan karena peruntukannya bukan untuk kalangan pendidikan menengah ke bawah yang merupakan bagian terbesar dari komunitas masyarakat Desa Srikaton. Sementara koleksi Pusdes akan buku-buku untuk kalangan anak-anak terasa masih kurang dan koleksiyang ada tapi sudah usang atau rusak jumlahnya ada puluhan. Seri majalah anak-anak yang disukai anak-anak kecil kebanyakan sudah lusuh. Ke depan masih perlu dilakukan penambahan koleksi untuk anak-anak setingkat SD kelas 1-2.

Untuk mensosialisasikan tentang reaktivasi pelayanan Perpustakaan Desa kepada anak-anak calon pengguna maka Tim PPM melakukannya melalui agen perantara yaitu Relawan Pusdes dan Pamong Didik dari Lembaga Sekolah. Cara yang dilakukan oleh relawan adalah melalui pemberitahuan berantai secara lisan dari mulut ke mulut. Awalnya relawan memberitahu beberapa anak kemudian anak-anak tersebut memberitahukan kepada teman-temannya.

Sosialisasi melalui Pamong Didik suatu lembaga sekolah ditempuh dengan melakukan kunjungan ke Sekolah Dasar Negeri 7 Pondok Kelapa dan Madrasah Diniyah 
Awaliyah Desa Srikaton pada awal bulan September, pertengahan Oktober, dan pertengahan Nopember. Melalui pamong didik di kedua lembaga pendidikan tersebut diberitahukan kepada anak-anak (siswa) bahwa Pusdes di Balai Desa sudah dibuka kembali untuk memberikan layanan peminjaman buku kepada mereka dengan jadwal layanan 2x seminggu pada hari Sabtu sore dan Minggu pagi. Tim menyampaikan harapan agar guru mendorong siswa untuk memanfaatkan Pusdes sebagai sumber informasi ketika harus menyelesaikan tugas-tugas sekolahnya dan menjadikannya sebagai alternatif tempat "belajar dan bermain" anak-anak.

Selain itu sosialisasi juga dilakukan melalui orang tua (ibu-ibu) yang tergabung dalam kelompok lansia wanita Desa Srikaton. Kelompok ini cukup eksis, kegiatannya antara lain melaksanakan senam kesehatan setiap Minggu pagi mulai jam 06.00, pertemuan rutin bulanan, koperasi, arisan, PKK, dan mendukung kegiatan desa. Tim menyampaikan harapan agar ibu-ibu ini mendorong anak-anak atau cucu mereka untuk datang ke dan membaca koleksi Perpustakaan Desa. Dukungan yang baik untuk tersosialisasinya dan terselenggaranya program reaktivasi Pusdes telah diberikan oleh Ketua Tim Penggerak PKK Desa yang menjadi bagian dari kelompok lansia ini.

Hibah buku diberikan kepada Perpustakaan Desa Srikaton dan Perpustakaan Sekolah Dasar Negeri 7 Pondok Kelapa. Buku-buku berasal dari pembelian oleh 2 Tim PPM dari Jurusan Sosiologi yaitu Tim ini sendiri yang dibiayai Dana BOPTN UNIB dan Tim lain yang dibiayai Dana RBA DIPA FISIP serta sumbangan dari Komunitas Belagham Bengkulu. Buku yang dibeli meliputi 67 judul yang terdiri 108 eksemplar buku senilai Rp. 5.029.800. Sedangkan buku sumbangan meliputi 19 judul yang terdiri 35 eksemplar buku. Pembelian buku-buku hibah dilakukan melalui agen CV Pertelon Media Cipta Bengkulu dan Toko Buku Magek Persada Bengkulu. Sesuai dengan kebutuhan kelompok sasaran, maka pengadaan buku difokuskan pada buku yang mendukung pembelajaran sekolah SD dan SMP, dan beberapa buku fiksi.

Selain itu diberikan hibah peralatan untuk operasional pengelolaan Perpustakaan Desa. Peralatan untuk penyelenggaraan perpustakaan yang ada memang sifatnya masih sederhana. Pengadaan peralatan seperti rak buku, karpet untuk pengunjung membaca lesehan, meja dan kursi untuk petugas, meja baca pengunjung, dan alat-alat kebersihan untuk bahan pustaka dan ruangannya sudah disediakan oleh pihak desa. Tim PPM menyediakan sarana penunjang untuk administrasi, pengolahan, dan perlengkapan bahan pustaka. Sarana penunjang non perabot ini kelihatannya remeh. Namun karena jumlah itemnya cukup banyak maka nilai nominal akhir tidak bisa dianggap kecil. Total dana yang dibelanjakan untuk sarana non perabot ini berjumlah Rp 271.000,-

Berdasarkan sejarah perjuangan bangsa, tanggal 28 Oktober 1928 Kaum Pergerakan Kemerdekaan Indonesia mendeklarasikan Sumpah Pemuda yang menyatakan berbangsa satu Bangsa Indonesia; berbahasa (persatuan) satu Bahasa Indonesia, dan bertanah-air satu Tanah-air Indonesia maka setelah era Proklamasi Kemerdekaan RI, tanggal 28 Oktober ditetapkan pemerintah sebagai Hari Sumpah Pemuda dan Bulan Oktober sebagai Bulan 
Bahasa Indonesia. Untuk merayakan Bulan Bahasa tersebut Tim PPM menyelenggarakan beberapa lomba seni untuk anak-anak pengguna Perpustakaan Desa tingkat SD dan SMP. Sosialisasi lomba dilakukan sejak 4 Oktober 2014. Sedangkan acara perlombaan itu dilaksanakan pada tanggal 19-25 Oktober. Pengumuman pemenang dan pembagian hadiah/insentif diberikan pada puncak perayaan Bulan Bahasa hari Minggu, 26 Oktober. Kegiatan lomba ini ditujukan untuk semakin meningkatkan kecintaan masyarakat kepada Perpustakaan Desa.

Secara formal perpustakaan desa ini sebenarnya sudah ada sejak 2010 karena bahan pustaka sebagai unsur utama perpustakaan sudah dimiliki yaitu 1.000 eksemplar buku yang berasal dari bantuan Badan Perpustakaan Provinsi Bengkulu. Hanya saja pada tahun tersebut buku-buku tidak dapat dilayankan (dibaca atau dipinjamkan) kepada masyarakat yang ingin membaca karena ketiadaan pengelola yang bertanggung jawab atas pengelolaan buku-buku tersebut. Pihak desa tidak mau asal meminjamkan kepada masyarakat karena khawatir buku-buku tersebut tidak dikembalikan lagi. Pihak desalah yang bertanggungjawab atas keberadaan buku-buku tersebut sehingga jika Badan Perpustakaan Daerah Bengkulu sewaktu-waktu mengecek keberadaaan buku bantuan tesebut pihak desa harus bisa memberi pertanggungjawaban yang jelas.

Selanjutnya adanya Program PPM Tim Sosiologi UNIB pada 2011 dan 2012 dapat membantu pemanfaatan layanan buku-buku tersebut. Adanya seorang relawan petugas yang disediakan oleh tim pengabdian benar-benar sangat memotivasi desa untuk mengelola buku-buku koleksi sebagaimana layaknya sebuah perpustakaan desa. Apalagi biaya operasional penyelenggaraan perpustakaan, ATK \& honorarium petugas, selama 2 tahun sepenuhnya ditanggung oleh tim PPM UNIB. Selama 2011-2012 Pusdes aktif berjalan berkat pendampingan Tim UNIB. Aparat desa dan para pemuka masyarakat berharap operasional perpustakaan desa benar-benar bisa berjalan dan berfungsi untuk meningkatkan minat baca dan pengetahuan masyarakat. Pengoperasionalan perpustakaan mulai dijalankan kembali pada 2014 setelah kevakuman pada 2013 berkat kehadiran kembali Tim PPM UNIB. Pengelolaan Pusdes dijalankan lagi dengan memberikan layanan peminjaman buku pustaka keluar (dibawa pulang pengguna) oleh petugas sekaligus sambil terus mengolah bahan-bahan pustaka dan membenahi administrasi yang belum terolah. Pengoperasionalan perpustakaan itu dilaksanakan karena pengelola dan perangkat administrasinya sudah tersedia. Jika harus menunggu sampai selesai pengolahan bukunya maka waktunya terlalu lama sehingga masyarakat tidak bisa langsung memanfaatkannya. Operasionalisasi dalam kurun 2011-2012 dilakukan dengan cara perpustakaan membuka tiga kali hari layanan per minggu pada waktu sore hari. Tahun 2014 saat PPM ini dilaksanakan, Pusdes membuka layanan peminjaman buku keluar (dibawa pulang rumah) 2 kali per minggu pada hari Sabtu dan Minggu. Namun untuk baca di tempat dapat dibuka setiap hari kerja Kantor Desa. Tim berkomitmen bahwa pendampingan pada Pusdes Srikaton akan dilakukan hingga Maret/April 2015. Pendampingan secara periodik akan dilakukan setidak-tidaknya setiap sebulan sekali. 


\section{KESIMPULAN DAN SARAN}

\section{Kesimpulan}

Program pengabdian pendampingan Perpustakaan Desa Srikaton tahun 2014 oleh Tim PPM Sosiologi Fisip telah selesai dilaksanakan dan dapat mengaktifkan kembali operasional Pusdes dari masa kevakuman sebelumnya. Tujuan kegiatan PPM dapat dilaksanakan semua. Hibah buku sebanyak 86 judul terdiri 143 eksemplar telah diberikan. Pengadaannya berasal dari pembelian oleh kerjasama dua Tim PPM Fisip senilai lima juta rupiah lebih dan dari sumbangan buku oleh komunitas Belagham Bengkulu. Hibah buku lebih banyak difokuskan pada kebutuhan pengguna yaitu buku penunjang pembelajaran sekolah dan pengetahuan umum tingkat Sekolah Dasar dan Sekolah Menengah Pertama sehingga hanya sebagian kecil berupa fiksi.

Pendampingan pengelolaan perpustakaan secara terstandard dilaksanakan sejak Agustus 2014 hingga direncanakan dapat berlangsung terus sampai dengan April 2015 dengan cara menempatkan seorang alumnus D3 Perpustakaan Fisip UNIB yang berdomisili di desa setempat sebagai relawan pengelola Pusdes. Hibah peralatan perlengkapan operasional perpustakaan senilai dua ratus tujuh puluh ribu lebih telah diberikan untuk menunjang jalannya pelaksanaan pengelolaan perpustakaan secara terstandard (profesional).

Aktivitas kreatif edukatif berbasis perpustakaan berupa lomba mewarnai dan lomba menulis ringkasan buku untuk anak-anak SD serta lomba bertutur cerita untuk siswa SMP telah dilaksanakan guna memperbesar kemanfaatan perpustakaan bagi masyarakat pengguna, sekaligus meningkatkan jumlah warga yang berkunjung ke Pusdes. Dukungan Perangkat Desa dan warga masyarakat kiranya menjadi bagian tak terpisahkan dari keberhasilan kegiatan ini.

\section{Saran}

Dengan purnanya kegiatan PPM 2014 ini selanjutnya disarankan sebagai berikut:

1. Pendampingan Pusdes Srikaton perlu dilanjutkan ke Program Pengabdian Masyarakat tahun 2015 untuk membantu menguatkan kelembagaannya dalam masyarakat dan kancah kepustakaan regional maupun nasional. Sosialisasi ke Sekolah Dasar dan Sekolah Menengah Pertama atau yang sederajad yang berdiri di desa ini perlu dilakukan untuk menjaring pengguna yang lebih banyak sehingga semakin meningkatkan keberfungsionalan Pusdes. Sangat disadari bahwa pengguna Pusdes dari kalangan siswa SMP saat ini masih sedikit dan tak banyak yang mengetahui bahwa koleksi perpustakaan desa ini memiliki buku-buku yang sesuai dengan kebutuhan mereka (anak SMP).

2. Selama berlangsung program PPM 2014 cara pendampingan pengelolaan Pusdes dilakukan dengan memantau kinerja perpustakaan melalui pengelolanya. Pendampingan di tahun-tahun berikutnya kiranya masih diperlukan. Untuk lebih meningkatkan kualitas standar administrasi perpustakaan, sebaiknya pengguna tetap 
perpustakaan ini dapat mulai dibuatkan kartu anggota perpustakaan. Ini penting dilakukan untuk mengetahui perkembangan keanggotaan dan ketertiban administrasi layanan sirkulasi (peminjamam dan pengembalian) di perpustakaan.

3. Upaya meningkatkan kehadiran pengguna perpustakaan melalui pengembangan aktifitas kreatif edukatif berbasis layanan Pusdes (seperti belajar mewarnai, menggambar, dan bercerita) perlu terus dilakukan agar kemanfaatan Pusdes bagi masyarakat sebagai pusat kegiatan belajar tetap dapat dipertahankan.

\section{UCAPAN TERIMAKASIH}

Dengan telah selesainya kegiatan pengabdian pada masyarakat ini, tim pelaksana mengucapkan terimakasih kepada pimpinan Universitas Bengkulu yang telah mengalokasikan anggaran DIPA 2014 guna membiayai seluruh kegiatan pengabdian ini. Selain itu, tim pelaksana juga mengapresiasi Ketua beserta segenap staf Lembaga Penelitian dan Pengabdian pada Masyarakat Universitas Bengkulu atas penilaian, pemantauan, dan fasilitasi administrasi dari awal kegiatan hingga pengadian purna.

\section{DAFTAR PUSTAKA}

Hanum, Sri Handayani, 2013, Penguatan Ketrampilan Pengelolaan Perpustakaan Sekolah Untuk Meningkatkan Semangat Pembelajaran Guru Yang Mendukung Pengembangan Prestasi Siswa, Laporan Pelaksanaan kegiatan Pengabdian Pada Masyarakat, Universitas Bengkulu.

Mudjito, 2001, Pembinaan Minat Baca, Universitas Terbuka, Jakarta.

Noerhayati, Soedibyo, 1987, Pengelolaan Perpustakaan Jilid I, Alumni, Bandung.

Sutrano, 2008, Membina Perpustakaan Desa, Sagung Seto, Jakarta. 